\title{
Sustainable Leadership Practices through students- community engagement for Sustainable Development Goals (SDG) in East Coast Malaysia
}

\author{
Hadijah Ahmad \\ Department of Social Science, Centre for Human Sciences, Universiti Malaysia Pahang, \\ Lebuhraya Tun Razak, 26300 Gambang, Kuantan, Pahang, Malaysia
}

\begin{abstract}
The environmental issues has become the growing concern since it is highlighted massively in the Malaysia SDG Voluntary National Review 2017 and Malaysia is ambitious in taking the commitment. The aims of SDG is to tackle the critical issue of pollution, food waste, climate change, illegal trade in wildlife as well as sustainable production and consumption. There are a lot of environmental drives for comprehensive implementation in SDG however, the groundbreaking data tells the strategies formulated by UNESCO in integrating the sustainable education framework to raising the awareness and tapped the sense of responsibility in combating environmental issues and climate change is not enough to spur people sensitivity to take action The late start of SDG integration in the curriculum has a disastrous implication when society does not have the right perspectives in the form of enlightenment of what SDG might hold in the future. To further sheds the light on the real matters is, Malaysian and the attitude of littering is a never ending stories. Lack of sustainable Development Goals (SDG) into curricula and educational programs has been said in the UN. Mohammed in 2018 asserted education as a crucial component to gear the SDG. In addressing the serious impact of pollution and climate change, Malaysian are urged to inculcate the environmental knowledge in students through the environmental education in a more hands-on delivery. Thus, the prime objective formulated is shed light into level of awareness, perception and challenges of sustainable leadership practices through studentscommunity engagement via applied mechanism in shaping future leaders by increasing the number of environmental activist for sustainability practices towards SDG initiatives. This study has been conducted in east coast Malaysia involving 275 students along with 115 participant (community) as the engagement from the society. The study conducted are using survey and semistructured interview and compliment the need of investigation on awareness, perception and challenges of sustainable leadership practices through SDG action.
\end{abstract}

Keywords: Sustainable leadership;students-community engagement; Sustainable Development Goals (SDG), awareness, challenges

\section{INTRODUCTION}

$\mathrm{T}$ task of MACC (Malaysian Anti-Corruption Commission) does no longer look at the public order or domestic corruption, instead they had widened their focus on the environment related corruption includes the offences towards timber, pollutions, poaching and other related environmental issues (The Star, 27th September 2019). DOSM also list out 4 components in the environmental statistics in Malaysia such as environmental conditions and quality, environmental resources and their use, component and residuals, extreme event and disasters, human settlement and environmental health and environmental protection, management and engagement (DOSM, 2018). From the list, there are 2.02 tonnes (million) of waste generated in Malaysia and this number shows that Malaysia is not ready to embrace the Sustainable Development Goals (SDG). The challenge is to educate people on how the environment matters and more active plan should be initiated (Aziz, Lukhman, Chubo \& Daud, 2019)

Department of Soft Skills UMP has taken the initiatives to instilled knowledge and shape the practices of soft skills through it sustainable education practices. Students are taught and be reminded about their roles to preserve, protect and love the environment. Sustainable education practices involved the way how human respect natural world. Hangreaves and Fink (2006) has stated human not only learn to know, learn to do, learn to live together, learn to be, but also they need to learn on how to respect natural world. In fostering the sustainable learning community, Hangreaves and Fink (2006) has outlined 7 sustainable leadership principles which is:

- creates and preserves sustaining learning

- secures success over time

- $\quad$ sustains the leadership of others

- addresses issues of social justice

- develops rather than depletes human and material resources

- develops environmental diversity and capacity

- undertakes activist engagement with the environment

With the 7 principles outlined, students are required to undertake the activist engagement with the environment. This connotes the idea of engage assertively with the environment that requires active participation from community. In order to build a better future, the present generation should embrace the sustainable development which respect, protect, preserve and renew all that is valuable in the past and learn from it (Hargreaves, 2007).s. 


\section{I.1. Background of Study}

Education play the vital part in gearing the environmental awareness since young (Rodzi, Mohd Nopiah \& Ahmad Basri, 2019; Hargreaves, 2007). The responsibility by us to spark an awareness on sustainability in terms of how we live our lives become the focal point on the transformation of ecosystem to sustained in the future (The Commonwealth 2017; Ferdig, 2007). The strategies formulated by UNESCO in integrating the sustainable education framework to raising the awareness and tapped the sense of responsibility in combating environmental issues and climate change is not enough to spur people sensitivity to take action (Vladimirova \& Le Blanc, 2015 p.p. 15-16). The late start of SDG integration in the curriculum has a disastrous implication when society does not have the right perspectives in the form of enlightenment of what SDG might hold in the future (Omisore, Babarinda, Bakare, \& Olanrimoye, 2017).

The conceptual framework for the study are illustrated as the following:

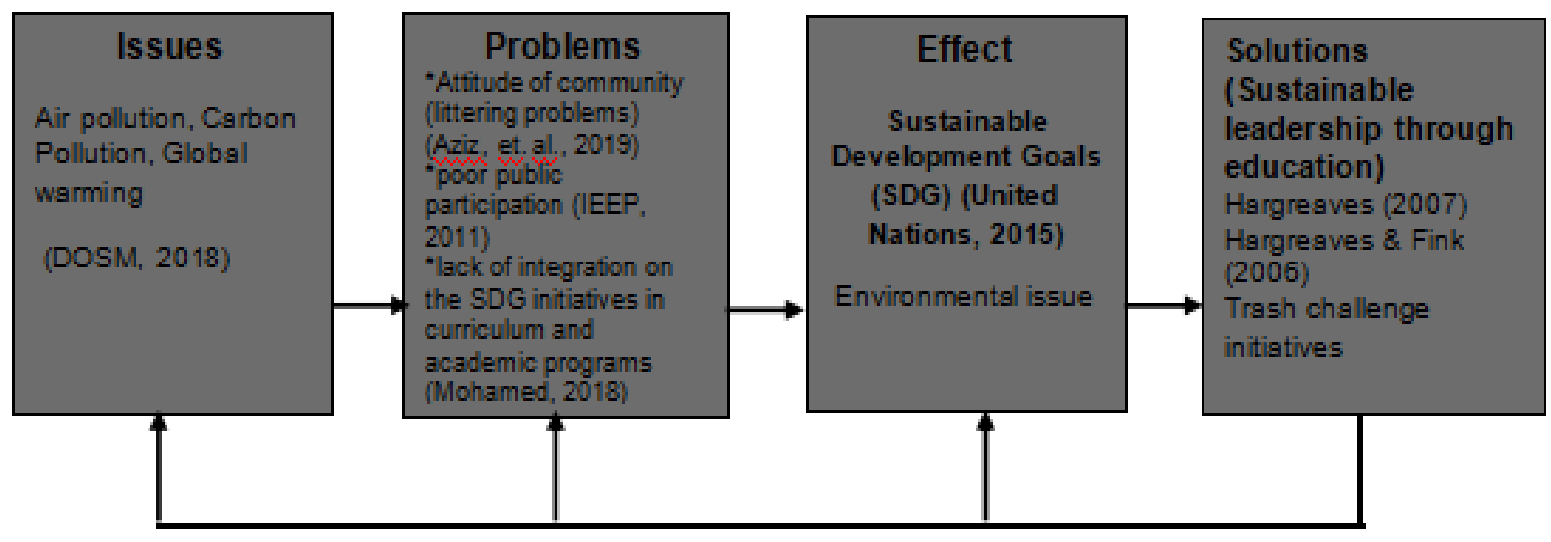

Figure 1: Conceptual framework of Sustainable Leadership Practices through students-community engagement for Sustainable Development Goals (SDG

\section{I.2. Problem Statement}

In Malaysia, environmental awareness among the public generally is still not adequate. In 1988, The Government of Malaysia had introduced the Action Plan for a Beautiful and Clean (ABC) Malaysia, followed by a recycling campaign in consecutive years. However, the campaigns do not lead to a positive result due to minimal responses from the public (Samsudin \& Don, 2013). In addition, it is found out the willingness to protect the environment and students understanding about the importance are lacking (Shamsuddin, 2003). Literally, a clean Malaysia stress out on the environmental issues which become the growing concern as there is a lackadaisical of society awareness in the sustainability initiatives (Aziz, et. al, 2019). As a consequence, load of environmental initiatives has been ventured to raise the awareness on pollution and climate change. To further sheds the light on the real matters is, Malaysian and the attitude of littering is a never ending story (Aziz, et. al., 2019; Samsudin \& Don, 2013). It is recorded people with low education have the high tendency to litter and imply that their cognitive, normative and affective character is not being shape well (Aziz, et. al., 2019). Lack of sustainable Development Goals (SDG) into curricula and educational programs has been said in the UN. Mohammed in 2018 asserted education as a crucial component to gear the SDG. In addressing the serious impact of pollution and climate change, Malaysian are urged to inculcate the environmental knowledge in students through the environmental education in a more hands-on delivery (Rodzi, et. al, 2019; Aziz, et. al., 2019). There is no specific Environmental Education (EE) in Malaysian Education system and there is a little attention given to the EE by teachers because there is no related exam involved (Noor Azlin et.al.). Through this means, educating young people on the importance of environmental knowledge is an enrichment process in life with deep fundamental purpose to nurture them for a better future leader (UNESCO; 2015; Hargreaves, 2007). Thus if there is no specific measures and implementation of SDG in education to combat pollution, Malaysia will be harmed by a catastrophic devaluation of environmental appreciation. Thus, the following reserach objective are formulated:

i. To investigate the level of awareness for students and community engagement of sustainable leadership for SDG practices

ii. To investigate participant perspectives on students and community engagement for SDG practices

iii. To explore the challenge of students and community engagement for SDG practice

The research question are formulated as following:

i. What is the level of awareness for students and community engagement of sustainable leadership for SDG practice?

ii. What is the participant perspectives on students and community engagement for SDG practices

iii. What is the challenge of students and community 
engagement for SDG practice

\section{LITERATURE REVIEW}

In explicating the sustainable leadership practices, review on literature of SDG, sustainable leadership practices and students-community engagement are detail out in the following section.

\section{II.1. Sustainability Development Goals (SDG)}

Malaysia is ambitious in taking the commitment to tackle the Sustainable Development Goals (SDG) in the three pillars namely economy, social and environment. This pillar is highly interconnected to promote economic growth with focus on use of man-made, natural, and social capital (Herath, 2017). The adoption of SDG as universal set of development targets is seen as necessary in combating a critical issues such as pollution, food waste, climate change, illegal trade in wildlife as well as sustainable production and consumption (UN Sustainable Development Goals, 2016). Efforts to gear the SDG initiatives is not a one sided commitment but require the element of education to change society for betterment.

\section{II.2. Sustainability Practices}

The cohesion policy and sustainable management (2011) has shed lights on the sustainability tools for consultation and public participation. In line with the SDG environmental pillar, the tools to promote this initiatives requires engagement with community. The introduction, promotion and application of tools for public are outlined as follows:

\begin{tabular}{|c|c|c|}
\hline No. & Delivery Mechanism & Instruments \\
\hline 1 & $\begin{array}{c}\text { Informal working } \\
\text { groups/networks }\end{array}$ & $\begin{array}{c}\text { Ensures partnership and public } \\
\text { participation, exchange of good } \\
\text { practices and innovative ideas }\end{array}$ \\
\hline 2 & Public consultations & $\begin{array}{c}\text { Ensures public participation in } \\
\text { decision-making of interested } \\
\text { stakeholders and awareness raising of } \\
\text { the general public }\end{array}$ \\
\hline
\end{tabular}

In relations, sustainable Development Goals (SDG) must be supported by the public engagement. There are varying context of community participation from involving themselves into decision making process to economic activities (Rasoolimanesh \& Jaafar, 2016). To develop a sustainable solutions for helping the community challenges, it demands collaboration, networking and interaction across group or culture (Timmer, 2007)

\section{II.3. Sustainable leadership}

The ideas of sustainable leadership are sparked by Hangreaves and Fink in 2006 whereas it is rooted in the idea of respecting the nature as a complimentary of Delors Report in 1996 (UNESCO, 1996). Leadership is a societal role, not just an individual mechanism for self-improvement. Leadership gives impact to the world for social change and environmental concern issues driven by the transformative environmental, sustainability and community influences (Timmer, 2007). Respect the natural world means have a deeper respect to environment and natural world and see world in the different ways and find out means to contribute to the community through education (Hargreaves, 2007; Hargreaves \& Fink, 2006). Sustainable leadership represents a growing purposeful consciousness among people who choose to live their lives and lead organizations in ways that compensate for a global economy's impact on earth , culture and health (Ferdig, 2000). Slankis (2006) outline 10 pillar of sustainable leadership as follows:

- change orientation -a willingness to change an organisation

- broad systems thinking - the ability to connect the organisation

- $\quad$ social and environmental consciousness - viewing the role of the organisation externally and its impact

- $\quad$ business savvy and credibility - linking sustainability and stakeholder value

- $\quad$ adaptability - manage, implement and change

- patience - commitment to the long-term

- translational skills - thought into action

- persuasiveness - communicating and building relationships

- energy and passion - communicate vision and encourage innovation to drive innovation

- mentoring and development - commitment to sound lasting leadership through development of people.

\section{METHODOLOGY}

To determine the appropriate research design, the researcher are opted for Creswell map as a guide and selected a qualitative research design. This allow in-depth understanding of the central phenomenon and interpretation of the leadership practices for sustainability destination management from student and community engagement through trash challenge. The selection is a testament of the researcher's credibility and skills in applying appropriate communication skills in interviewing the relevant individuals. Qualitative can be described as the means of understanding individuals or people through an exploration that involves question and procedures, whereby data is typically collected in participant's setting. The essential features in conducting a qualitative research includes the topics of research, data collection methods and fieldwork setting for data collection purposes (Creswell, 2009; Yin, 2011).

The nature of action research tended to cater social aspect rather than the individual perspectives and the inclusion of this aspect is the opposite of solitary work (McNIff, 2017; Somekh, 2006). The commitment to employ collaborative action research in qualitative nature requires (McNiff, 2017):

i. Active involvement of practitioners as agent

ii. More open methodology and open-ended developmental

iii. Besides of improving the social intent, the aims is to improve learning 


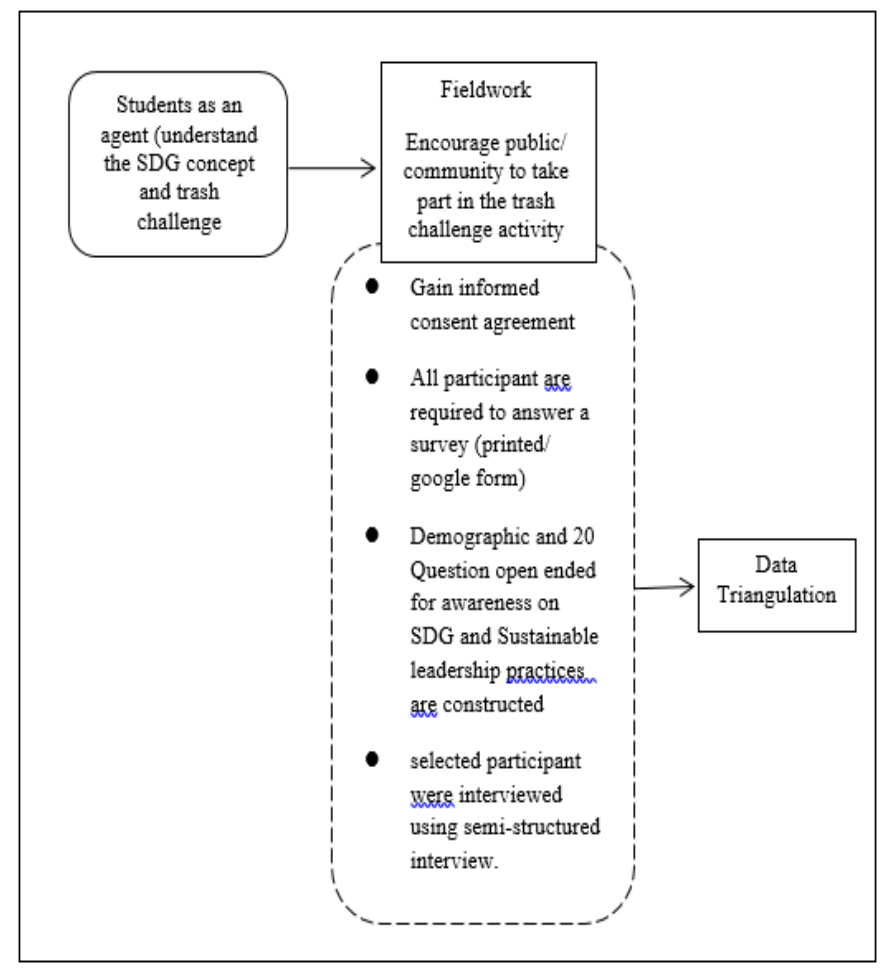

Figure 2: Process of inquiring information (Creswell, 2014; Creswell, 2007/2009, Somekh, 2006; Berg, 2001)

\section{III.1. Sampling}

Sampling is done depending on the people to be observed, the interview setting, events and social processes (Miles \& Huberman, 1994). A purposive sampling will be carried out because they are more inclined to know the reason behind the construction of a particular person, group or process, which will mold the vital ideas in finding the right person and their location within a group (Given, 2008).

A more hands on experience and assessment will be done to inculcate the awareness and positive attitude towards waste management for UMP students particularly for Soft Skills students. The implementation of this hands on activity will take place not for UMP students only, but towards the primary and secondary students as well. To embrace the leadership capacity, they act as a little ambassador for the university in terms of SDG initiatives.

More specifically, they are required to spark the initiatives of inviting others and be the nucleus to influence community to participate in the activities of trash challenge. For the purpose of this study, there are various type of sampling will be involved. Larger number of participants will ensure greater confidence for the findings (Yin, 2011). Purposive sampling will be carried out for this study. There are two general knowledge on sampling which is purposive sampling and nonpurposive sampling. For qualitative study purposive sampling is widely used because it is selective, rely on the judgement of researcher that sample selected fit with the nature of study
(Creswell, 2007). The matrix for the samples are tabulated in the following table:

Table 1: Characteristic of Sample

\begin{tabular}{|c|c|c|c|}
\hline No & Sample & Characteristic & Location \\
\hline 1 & $\begin{array}{c}\text { Students : } \\
\text { In year 1 } \\
\text { undertake Soft } \\
\text { Skills Subject) }\end{array}$ & $\begin{array}{l}\text { Understand the objectives } \\
\text { of nurturing sustainable } \\
\text { leadership through the } \\
\text { agenda of : } \\
\text { - Responsibility as a } \\
\text { human to respect, } \\
\text { preserve and protect } \\
\text { the environment } \\
\text { The impact of their } \\
\text { action for } \\
\text { sustainable } \\
\text { destination } \\
\text { management } \\
\text { The Sustainable } \\
\text { Development Goal } \\
\text { (SDG) agenda } \\
\text { The trash challenge } \\
\text { activities }\end{array}$ & $\begin{array}{l}\text { Through } \\
\text { the } \\
\text { selected } \\
\text { location in } \\
\text { Kuantan } \\
\text { and } \\
\text { Pekan, } \\
\text { Pahang }\end{array}$ \\
\hline 2 & $\begin{array}{l}\text { Public Participation: } \\
\text { community who has } \\
\text { prompt and } \\
\text { impromptu action in } \\
\text { joining the trash } \\
\text { challenge activity } \\
\text { Prompt action } \\
\text { (agree to participate } \\
\text { after being informed } \\
\text { by social media or } \\
\text { other means } \\
\text { Impromptu action } \\
\text { (agree to participate } \\
\text { during the trash } \\
\text { challenge without } \\
\text { prior information on } \\
\text { the event) }\end{array}$ & $\begin{array}{l}\text { Understand the objectives } \\
\text { of nurturing sustainable } \\
\text { leadership through the } \\
\text { agenda of : } \\
\text { - Responsibility as a } \\
\text { human to respect, } \\
\text { preserve and protect } \\
\text { the environment } \\
\text { The impact of their } \\
\text { action for sustainable } \\
\text { destination } \\
\text { management } \\
\text { The Sustainable } \\
\text { Development Goal } \\
\text { (SDG) agenda } \\
\text { The trash challenge } \\
\text { activities }\end{array}$ & $\begin{array}{l}\text { Through } \\
\text { the } \\
\text { selected } \\
\text { location in } \\
\text { Kuantan } \\
\text { and } \\
\text { Pekan, } \\
\text { Pahang }\end{array}$ \\
\hline
\end{tabular}

\section{FINDINGS AND DISCUSSION}

The findings of the study are divided into 3 parts includes Demographic, students and community opinion on the SDG activities and thematic analysis.

i. To investigate the level of awareness for students and community engagement of sustainable leadership for SDG practices

ii. To investigate participant perspectives on students and community engagement for SDG practices

iii. To explore the challenge of students and community engagement for SDG practice

\section{IV.1. Demographic}

There are 257 students participated in the study. The students are divided into group with approximately 8 to 9 members in the group and they are responsible to engage the community in taking part in leadership sustainability initiatives (the trash challenge). They are required to brief anyone near the location of trash challenge, promote the activities, do it together and answer an open ended questionnaires via google form. Hard copy are ready to assist participants who refuse to answer through phone or to those who does not have access to the 
google form. The group are randomly pick any of 3 participants and interview them with consent agreement. The following findings are tabulated in the table 2

Table 2: Demographic

\begin{tabular}{|c|c|c|}
\hline Section & Group & $\begin{array}{c}\text { No. of } \\
\text { community } \\
\text { participation }\end{array}$ \\
\hline $7 \mathrm{G}$ & 60 students (7 Group) & 30 \\
\hline $18 \mathrm{P}$ & 60 students (7 Group) & 15 \\
\hline $21 \mathrm{P}$ & 35 students (7 group) $: 4$ members & 25 \\
\hline $15 / 16 \mathrm{LD}$ & 60 students (7 Group) & 45 \\
\hline $23 / 24 \mathrm{ED}$ & 60 students (7 Group) & 41 \\
\hline Total & 275 students & 115 \\
\hline
\end{tabular}

The table presented indicates each group has an average participation of 3.28 from a community participant. There is no coercion in decision making for each participation. This means, the community have positive attitude towards participating in a trash challenge as one of the cleaning campaign initiate by Soft Skills Department. They believe the shared responsibilities between students and community as SDG commitment is not a one sided effort.

\section{IV.2. Students-community opinion}

A descriptive data on students opinion and public opinion and future expectation of the activity are revealed based on the following table:

Table 3: Descriptive findings

\begin{tabular}{|c|c|c|}
\hline Question & Students & Public \\
\hline $\begin{array}{c}\text { Do you agree if this event is } \\
\text { made as a routine activities? }\end{array}$ & $\begin{array}{c}96.1 \% \\
\text { agree }\end{array}$ & $\begin{array}{c}\text { 95\% agree } \\
\text { (public) }\end{array}$ \\
\hline $\begin{array}{c}\text { If there is any same future } \\
\text { events conducted, would you } \\
\text { mind to participate? }\end{array}$ & $\begin{array}{c}76 . \% \text { love } \\
\text { to } \\
\text { participate }\end{array}$ & $\begin{array}{c}93 \% \text { love } \\
\text { to } \\
\text { participate }\end{array}$ \\
\hline
\end{tabular}

Table 3 indicate the responses from students and public participant on their opinion for this trash challenge activities with majority of them agree to make the event as a routine with $96.1 \%$ students agree and $95 \%$ public agree. Expectation of students and public on SDG practices through trash challenge revealed $76 \%$ of students love to participate and 93\% public would love to participate in the near future. Thus, the findings of these answered briefly the research question 1 which are investigate the level of awareness for students and community engagement of sustainable leadership for SDG practices.

\section{IV.3. Thematic analysis}

Interview session are conducted among community with semi structured interview question. The labeling of participant as ' $\mathrm{P}$ ' (participant) are one of the ethical requirement in protecting the identity. Result of open ended question and community interview are extracted in the verbatim quotes format as follows:
Table 4: the participant perspectives on students and community engagement for SDG practices

\begin{tabular}{|c|c|c|}
\hline $\begin{array}{l}\text { Theme and } \\
\text { Sub-theme }\end{array}$ & Excerpt & Sources \\
\hline $\begin{array}{l}\text { Theme: } \\
\text { Engagement } \\
\text { ST: urgency } \\
\text { to promote } \\
\text { the activity }\end{array}$ & $\begin{array}{l}\text { 'this kind of activity } \\
\text { can spread widely } \\
\text { among the people and } \\
\text { the effort to protect the } \\
\text { environment become } \\
\text { even better' (P11) } \\
\text { 'it is good to have this } \\
\text { activities for public to } \\
\text { participate (P4) }\end{array}$ & $\begin{array}{l}\text { Environmental education } \\
\text { should be start from } \\
\text { earlier of age on younger } \\
\text { generation due to they are } \\
\text { as a future leader are so } \\
\text { important } \\
\text { (Aminrad, 2012) }\end{array}$ \\
\hline $\begin{array}{c}\text { Theme: } \\
\text { SDG Action } \\
\text { ST: } \\
\text { education }\end{array}$ & $\begin{array}{l}\text { 'Awareness on } \\
\text { cleanliness should be } \\
\text { inculcate start from } \\
\text { yourself' }(\mathrm{P} 10, \mathrm{P} 11)\end{array}$ & $\begin{array}{l}\text { Promoting sustainability } \\
\text { should be done via: - } \\
\text { Shape the future leaders } \\
\text { in school and universities } \\
\text { with means of instilled } \\
\text { the ambition and } \\
\text { inspiration to develop } \\
\text { practical knowledge for } \\
\text { society } \\
\text { - Raise public } \\
\text { participation by creating } \\
\text { an enabling environment } \\
\text { for participation }\end{array}$ \\
\hline $\begin{array}{l}\text { Theme: } \\
\text { Sustainable } \\
\text { Leadership } \\
\text { ST: Pillar of } \\
\text { sustainable } \\
\text { leadership }\end{array}$ & $\begin{array}{l}\text { 'We appreciate the } \\
\text { initiative of the } \\
\text { students by } \\
\text { encouraging society } \\
\text { and young people } \\
\text { participating in this } \\
\text { kind of activity. As you } \\
\text { can see, children love } \\
\text { this' (P3) } \\
\text { 'Program on } \\
\text { cleanliness should be } \\
\text { encourage. } \\
\text { Participation on such } \\
\text { activity at young age } \\
\text { should be foster' (P 10) }\end{array}$ & $\begin{array}{l}\text { The activity of waste } \\
\text { cleaning does not only } \\
\text { serve the purpose of } \\
\text { cleaning but creates a } \\
\text { sense of unity and } \\
\text { friendship and motivate } \\
\text { people to commit in the } \\
\text { shared responsibility } \\
\text { (Rangeti \& Dzwairo, } \\
\text { 2021) }\end{array}$ \\
\hline
\end{tabular}

To answer the second research question which are investigating participant perspectives on students and community engagement for SDG practices, table 3 are presented. Participant has a positive view in the trash challenge activities geared by students. Community participation is imperative to the success of SDG practices, therefore the engagement between students and community is a proactive measure for SDG action. As excerpted, the promotion of the activities is an effective tools to inculcate environmental education and promotes it in a various way. It is said that such exposure should be taught to younger generation at their earliest age. The activities not only consider as meaningful to the public, it is also fit with SDG actions in encouraging the outcome of a sustainable future leader. The quest for fully achieving the SDG will be made possible if education intervene and reconcile in the foundation of teaching and learning (Hargreaves, 2007)

The challenges of students and community engagement are tabulated in the following table: 
Table 5: The challenge of students and community engagement for SDG practice

\begin{tabular}{|c|c|c|}
\hline $\begin{array}{l}\text { Theme and } \\
\text { Sub-theme }\end{array}$ & Excerpt & Sources \\
\hline $\begin{array}{l}\text { Theme: } \\
\text { Attitude } \\
\text { ST: urgency to } \\
\text { promote the } \\
\text { activity }\end{array}$ & $\begin{array}{l}\text { 'I want other people care about } \\
\text { environment' (P6) } \\
\text { 'People attitude should be } \\
\text { change even we did a routine } \\
\text { activity for cleaning' (P20) }\end{array}$ & $\begin{array}{l}\text { One of major challenge } \\
\text { in environmental } \\
\text { education (EE) is } \\
\text { changing people's attit } \\
\text { ude to be more environ } \\
\text { mentally friendly. } \\
\text { (Aminrad, 2012) }\end{array}$ \\
\hline $\begin{array}{l}\text { Theme: } \\
\text { Integration } \\
\text { ST: } \\
\text { Stakeholder } \\
\text { participation }\end{array}$ & $\begin{array}{l}\text { 'Please look around. There is } \\
\text { almost NONE of the trash bin } \\
\text { provided in this neighborhood' ( } \\
\text { P10) } \\
\text { 'Lack of trash bin are the main } \\
\text { reason why littering is } \\
\text { happening' (P12) } \\
\text { 'immediate action should be } \\
\text { taken by authorities regarding the } \\
\text { pick up time of the trash bin. } \\
\text { Usually, in the park, they let the } \\
\text { trash full. It is over flooded' (P5) } \\
\text { 'Authorities doesn't provide trash } \\
\text { bin' (P10,P 15) } \\
\text { 'Cleaning system still in a } \\
\text { traditional way, whereby we } \\
\text { have to dispose it by ourselves' } \\
\text { (P20) }\end{array}$ & $\begin{array}{l}\text { In most cases and } \\
\text { many part of the world, } \\
\text { destination } \\
\text { management functions } \\
\text { were put under the } \\
\text { responsibility of local } \\
\text { authorities where they } \\
\text { are having constraints } \\
\text { to go beyond the } \\
\text { context of adoption on } \\
\text { the stakeholder } \\
\text { participation } \\
\text { (Conaghan, Harahan \& } \\
\text { McLaouglin, 2015; } \\
\text { Brokaj, 2014). }\end{array}$ \\
\hline
\end{tabular}

The theme revealed people attitude as one of the challenges hindered the effectiveness of SDG practices. People's attitudes towards cleanliness and understanding the consequences of waste management play a significant role in encouraging more participation to improve the SDG practices. By participating in a trash challenge, community can contribute in creating immediate and long-term impact to make the world a better place. Trash can serve as catalysts for permanent changes in behaviour and attitude as well as encouraging communities to adopt good practices with basic application such as respond to the environment by not littering and pick up the trash, which have a profound effect in a community.

Other challenge highlighted are stakeholder participation where people view are prone towards the sole responsibilities of authority. This in turn creates a blame game and reserve a pessimistic culture where society believed authority should fulfill the mandate of clean and safe environment. As a result, it hinder the active community participation for successful SDG practices. The collaborative effort in cleaning the environment via trash challenge can send a clear message to the community members the importance of their role as an agent for a clean and safe environment.

\section{RECOMMENDATION AND CONCLUSION}

The study conducted has succeed in addressing the need for investigation on level of awareness for students and community engagement, participant perspectives and the challenge of students and community engagement for SDG practices. Community are actually ready to contribute for any initiative drive by government, authorities or any stakeholder because if these things left out, it will remain a big concern and challenging in the future. The activity of trash challenge carried out in the study is proven to educate communities on the importance of respecting the nature by being responsible as well as understanding the consequences of littering and dumping. The lack of environmental education as addressed can be procure by environmental education at school level. By having the activities initiated by students as an agent help community to understand their roles and to take control to be part of importance aspect for environmental movement. Such revelation fill the gap of sustainable leadership practices in terms of awareness, perception and challenges.

\section{ACKNOWLEDGEMENTS}

This study is carried out with support from Department of Social Science, Centre for Human Sciences, Universiti Malaysia Pahang

\section{REFERENCES}

[1] Aminrad, Z., Zakariya, S. Z. S., Hadi, A. S., Sakari, M., (2012). Environmental Education in Malaysia, Progresses and Challenges Ahead (Review). Life Science Journal. Vol. 9 (2). Retrieved from

https://www.academia.edu/3447950/Environmental_Education_in _Malaysia_Pro gresses_and_Challenges_Ahead

[2] Aziz, N. A. A., Lukhman, A. A, Chubo, J.K., and Daud D. S. R. A., (2019). Public Perception to Littering in Greenspaces: A Case Study in Bintulu, Sarawak, Malaysia. Journal of Physics: Conference Series, no. 1358 (2019) 012031 IOP Publishing doi:10.1088/1742-6596/1358/1/012031. Retrieved from https://iopscience.iop.org/article/10.1088/17426596/1358/1/012031/pdf

[3] Brokaj, R., (2014). Local government's role in the sustainable tourism development of a destination. European Scientific Journal November 2014 edition vol.10, No.31 ISSN: 1857 - 7881 . Retrieved from https:// destination+management+funtions\%3B+local+authority\&gs_l=ps y-ab.3...17067.22469..22807...0.2..0.120.1479.13j4.............gwswiz.......0i71j0i22i30j0i8i13i30j33i22i10i29i30j33i10i160.FxJMP RRTufU\&ved $=0$ ah

UKEwi5xODKiY_mAhUkheYKHSQTDEwQ4dUDCAs\&uact=5

[4] Conaghan, A., Harahan, J., McLaouglin, E., (2015). The Sustainable Management of a Tourism Destination in Ireland: A Focus on County Clare. Advances in Hospitality and Tourism Research (AHTR), Vol. 3 (1), p.p 62-87. Retrieved from https://www.researchgate.net/publication/289538374_The_Sustain able_Management_of_a_Tourism_Destination_in_Ireland_A_Foc us_on_County_Clare

[5] Creswell, J. W. (2014). Research Design: Qualitative, Quantitative and Mixed Methods Approaches (4th ed.). Thousand Oaks, CA: Sage

[6] Creswell, J. W. (2007). Qualitative Inquiry\& Research Design: Choosing Among Five Approaches.

[7] Creswell, J. W. (2009). Research Design: Qualitative, Quantitative and Mixed Method Approaches.

[8] Dalziel D., Hewitt E., Evans, L., (2007) Motivations and barriers to citizen. Governance communities Local Government London.

[9] Department of Statistic Malaysia (2018). Compendium of Environment Statistics 2018. Retrieved from https://www.dosm.gov.my/v1/index.php?r=column/cthemeByCat \&cat=162\&bul_id=U3p3RVY0aGtGS08yTDY2cEpraDFIUT09\& menu_id=NWVEZGhEVINMeitaMH NzK2htRU05dz09

[10] Ferdig, M. A., (2007). Sustainability Leadership: Co-creating a Sustainable Future, Journal of Change Management, 7:1, 25-35, DOI: $10.1080 / 14697010701233809$ 
[11] Fraser H., (2005). Four different approaches to community participation Community Development Journal

[12] Given, L. M. (2008). The Sage Encyclopedia of Qualitative Research Methods. The MIT Press. https://doi.org/10.4135/9781412963909

[13] Gruber, A. M., (2017). Community engagement in higher education. Vol 78, No 10 (2017). Retrieved from https://crln.acrl.org/index.php/crlnews/article/view/16809/18387

[14] Herath, G., (2017). Sustainable Development and the Environment: Issues for the Asian Region. Advances in Environmental Studies. Volume 1, Issue 1. Retrieved from https://scholars.direct/Articles/environmental-studies/aes-1004.php?jid=environmental-studies

[15] IEEP (Institute for European and Environmental Policy), (2011). The cohesion policy and sustainable development: supporting paper $5 . \quad$ Retrieved from https://ec.europa.eu/regional_policy/sources/docgener/studies/pdf/ sustainable_d evelopment/sd_supporting_paper_5.pdf

[16] Hargreaves, A. (2007). Sustainable Leadership and Development in Education: creating the future, conserving the past. European Journal of Education, Vol. 42, No. 2, 2007.

[17] Hargreaves, A., Fink, D., (2006). Sustainable leadership. Journal of Educational Change. March 2006, Volume 7, Issue 1-2, pp 105-107. https://doi.org/10.1007/s10833-006-0022-3

[18] McNiff, J., (2017). Action research: all you need to know. SAGE Publication Ltd.

[19] Miles, M. B., \& Huberman, A. M. (1994). Qualitative Data Analysis: An Expanded Sourcebook. Thousand Oaks, CA: Sage Publications

[20] Ministry of Education (MOE), (2020). Retrieved from https://www.moe.gov.my/en/statistik-menu/senarai-sekolahmengikut-kumpulan-jenis-dan-negeri http://www.data.gov.my/data/ms_MY/dataset/senarai-sekolahrendah-dan-menengah-di-negeri-pahang

[21] Mohammed, A. J., (2018). UNChronicle Vol. LV No. 22018

[22] New Strait Times (NST). (2018). Written by Ashley Greig. Enough is enough: stop the killer litter. Retrieved from https://www.nst.com.my/opinion/columnists/2018/05/373743/eno ugh-enoughstop-killer-litter

[23] Noor Azlin, Y., Chong, C.M., \& Azyyati, A.K. (2006). The implementation of environmental education in Malaysian schools : an NGO's overview". In Noor Azlin, Y., Philip, E, \& Ong. T. Proceedings of the Conference on Best of Both Worlds: Environmental Education for Sustainable Development. (pp. 7984). Kepong: Forest Research Institute Malaysia.

[24] Omisore, A. G., Babarinda, G. M., Bakare, D. P., \& Olanrimoye E. O. A., (2017). Awareness and Knowledge of the Sustainable Development Goals in a University Community in Southwestern Nigeria. Ethiopian Journal of Health Science, Nov; 27(6): 669-676. doi: 10.4314/ejhs.v27i6.12. Retrieved from https://www.ncbi.nlm.nih.gov/pmc/articles/PMC5811946/

[25] Rangeti, I., \& Dzwairo, B., (2021). Guide for organizing a community clean up campaign. Strategies of sustainable solid waste management. IntechOpen Ltd. DOI: 10.5772/intechopen.94515.

Retrieved

from https://www.intechopen.com/chapters/73972

[26] Rasoolimanesh, S.M., Jaafar, M., (2016). Community Participation toward Tourism Development and Conservation Program in Rural World Heritage Site. IntechOpen. http://dx.doi.org/10.5772/62293. Retrieved from https://www.intechopen.com/books/tourism-from-empiricalresearch-towards-practical-application/community-participationtoward-tourism-development-and-conservation-program-in-ruralworld-heritage-

[27] Rodzi, R. M., Mohd Nopiah, Z., \& Ahmad Basri, N. E. (2019). Environmental awareness and attitudes towards solid waste management among TVET students in Malaysia. International Journal of Innovative Technology and Exploring Engineering, 8(7), 387-392. Retrieved from https://ukm.pure.elsevier.com/en/publications/environmentalawareness-and- attitudes-towards-solid-waste-management

[28] Saldana, J. (2009). The Coding Manual for Qualitative Researchers. Los Angeles, CA: Sage Publications

[29] Samsudin, M. D. M., \& Don, M. M. (2013). Municipal solid waste management in Malaysia: Current practices, challenges and prospect. Jurnal Teknologi (Sciences and Engineering), 62(1), 95-101. https://doi.org/10.11113/jt.v62.1293

[30] Somekh, B., (2006). Action Research: a Methodology for Change and Development. Open University Press, McGraww Hill.

[31] Timer, D. (2007). Becoming a Sustainability Leader IISD's role in shaping the next generation of sustainable development leadership. International Institute for Sustainable Development (IISD)

[32] The Commonwealth (2017). Curriculum Framework for the Sustainable Development Goals. Retrieved from https://www.thecommonwealth-educationhub.net/wpcontent/uploads/2018/04/CFSDG_UPDF-003.pdf

[33] UN Sustainable Development Goals. (2016). Sustainable development goals: 17 goals to transform our world. Retrieved March 11, 2017, from http://www.un.org/ sustainabledevelopment/sustainable-development-goals/

[34] UNESCO (2015). Rethinking education towards global common good?. United Nations Educational, Scientific and Cultural Organization.

[35] UNESCO (1996). Delors Report: Learning the treasure within. Delors Comission, retrieved from https://unesdoc.unesco.org/ark:/48223/pf0000109590

[36] Vladimirova, K., \& Le Blanc, D., (2015). How well are the links between education and other sustainable development goals covered in UN flagship reports? A contribution to the study of the science-policy interface on education in the UN system. Department of Economic and Social Affairs (DESA) working paper no. 146. Retrieved from https://sustainabledevelopment.un.org/content/documents/2111edu cation\%20and\%20sdgs.pdf

[37] Yin, R. K. (2011). Qualitative research from start to finish. New York: Guilford 